Original Article

\title{
ANTIDIABETIC ACTIVITY AND TOXICOLOGICAL EVALUATION OF THE METHANOL- DICHLOROMETHANE ROOT BARK EXTRACT OF NAUCLEA DIDERRICHII (DE WILD) MERR
}

\author{
THEOPHINE C. AKUNNE, BONAVENTURE C. OBI*, MARTHA N. OFOKANSI, PATIENCE C. NWONU, CHARLES O. OKOLI \\ Department of Pharmacology and Toxicology, Faculty of Pharmaceutical Sciences, University of Nigeria, Nsukka, PMB 410001, Enugu \\ State, Nigeria \\ Email: bonaventure.obi@unn.edu.ng
}

Received: 06 Jun 2017 Revised and Accepted: 14 Aug 2017

\begin{abstract}
Objective: In southeastern Nigeria, Nauclea diderrichii (De Wild) Merr is used in the treatment of a wide range of ailments including diabetes mellitus (DM). This study evaluates the antidiabetic activity and toxicological profile of the methanol-dichloromethane root bark extract of $N$. diderrichii in normoglycemic and alloxan-induced diabetic models.

Methods: Dried root barks of $N$. diderrichii were extracted using methanol and dichloromethane (1:1) to obtain $N$. diderrichii extract (NDE). The acute and sub-chronic toxicity tests were performed using standard procedures. The effect on alanine aminotransferase (ALT) aspartate aminotransferase (AST), alkaline phosphatase (ALP), total protein (TP), packed cell volume (PCV), hemoglobin concentration (HB) and total white blood cell (TWBC) count was determined in the rats after treatment. In order to elucidate its antidiabetic mode of action, an oral glucose tolerance test (OGTT) was performed using glucose ( $2 \mathrm{~g} / \mathrm{kg}$ ) as substrate and alloxan (100 mg/kg; i. v.) induced diabetic model. Glibenclamide (GLI 0.2 $\mathrm{mg} / \mathrm{kg}$ ) was used as the reference standard drug.
\end{abstract}

Results: The results indicated that the $\mathrm{LD}_{50}$ of the extract is $>5000 \mathrm{mg} / \mathrm{kg}$. ALT, AST, ALP PCV, HB and TWBC were insignificantly (p>0.05) different compared with the control. No significant changes were observed in the organ weights compared with the control. In the acute and prolonged antidiabetic study, NDE $(100,200$ and $400 \mathrm{mg} / \mathrm{kg})$ significantly reduced the blood glucose level (BGL) by $14.66,18.9,25.80 \%$ and $75.11,80.24$, 83.74\% respectively. In comparison, GLI, when administered, reduced BGL by 38.18 and $92.86 \%$ respectively.

Conclusion: $N$. diderrichii possesses antidiabetic activity with good toxicological profile.

Keywords: Antidiabetic, Toxicity study, Biochemical and hematological parameters, Nauclea diderrichii

(C) 2017 The Authors. Published by Innovare Academic Sciences Pvt Ltd. This is an open access article under the CC BY license (http://creativecommons.org/licenses/by/4.0/] DOI: http://dx.doi.org/10.22159/ijpps.2017v9i9.20556

\section{INTRODUCTION}

Diabetes mellitus (DM) is one of the major health concerns worldwide. It is characterized by chronic hyperglycemia and associated abnormalities in carbohydrate, fat and protein metabolism, resulting from a deficiency in insulin secretion, action or both [1]. Currently, there are approximately 150 million diabetics worldwide and this number has been predicted to double by the year 2025. Its prevalence, high cost of antidiabetic drugs and the associated side effects of standard agents have necessitated the search for newer molecules from natural sources [2].

The natural environment is endowed with plant materials and fruits which have been found to be of great medicinal and nutritional importance. There are many experimental pieces of evidence indicating the use of plants for medicinal purposes, hence, the plant kingdom has become a target for the search of biologically active lead compounds for the complementary/alternative management of diabetes mellitus [3]. However, plant extracts can elicit different biological effects in the body, some of which may be harmful [4]. Thus, the toxicological evaluation of plant extracts is very necessary as this often helps to assess their safety in humans.

Few of the plants used in traditional medicine for the treatment of diabetes have received little scientific attention and Nauclea diderrichii (De Wild) Merr is one of such plants. Nauclea diderrichii is an ever green tree belonging to the Rubiaceae family. It is endemic in West and Central Africa and has been extensively studied for its antimalarial [5], antiplasmodial [6], antileishmanial [7] and antitrypanosomal [8] activities. In Nigerian folklore medicine, $N$. diderrichii is used in the management of a wide range of ailments ranging from endocrine disorders, infections, wound healing, antimalarial, anemia, stomach ache, indigestion, and others [9]. The present study was designed to evaluate the antidiabetic activity of $N$. diderrichii and its toxicity profile (acute and sub-chronic) in order to validate its folkloric use in the management of diabetes and to ascertain its level of safety.

\section{MATERIALS AND METHODS}

\section{Plant material and extraction procedure}

Fresh root barks of $N$. diderrichii were collected from Nsukka $\left(6^{\circ} 52^{\prime}\right.$ $0^{\prime \prime}$ North, $7^{\circ} 23^{\prime} 0^{\prime \prime}$ East), Enugu State, Nigeria in the month of July 2015. The plant sample was identified and authenticated by Mr. Alfred Ozioko of the International Centre for Ethnomedicine and Drug Development (InterCEDD), Nigeria, where the voucher specimen has been deposited under number Inter CEDD-0715. The fresh root barks were collected, peeled, cut, dried and pulverized into coarse powder. The powdered sample $(2 \mathrm{~kg})$ was extracted with a mixture of dichloromethane and methanol in the ratio of $1: 1$ by cold maceration in closed vessel with intermittent shaking for $48 \mathrm{~h}$. When maceration was completed, the macerated plant material was filtered using Whatman No 1 filter paper and the filtrate concentrated to dryness under reduced pressure and the crude $N$. diderrichii extract (NDE) was obtained.

\section{Animals}

Adult albino rats (100-160 g) and mice (15-30 g) of both sexes were obtained from the Animal House facility of the Department of Pharmacology and Toxicology, University of Nigeria, Nsukka, Nigeria. They were maintained under standard laboratory conditions $\left(22 \pm 2{ }^{\circ} \mathrm{C}, 12: 12 \mathrm{~h}\right.$ dark/light cycle, frequent air change) and had free access to water and standard animal feed ad libitum. All procedures were in compliance with the NIH Guidelines for Care and Use of Laboratory Animals (Pub No. 85-23, revised 1985), and in accordance with the University Ethical Committee on the use of laboratory animals. 


\section{Toxicological evaluation}

\section{Acute toxicity test $\left(\mathrm{LD}_{50}\right)$}

The acute toxicity test $\left(\mathrm{LD}_{50}\right)$ of the extract was carried out using Lorke's procedure [10]. Adult albino mice (15-30 g) of both sexes were used. The study was carried out in two stages. In the first phase, 9 mice were randomly divided into three groups $(\mathrm{n}=3)$, and were orally administered with the extract at 10,100 , and $1000 \mathrm{mg} / \mathrm{kg}$ dose levels, respectively. The animals were allowed free access to food and water; the results were recorded after $24 \mathrm{~h}$ which was used as a guide for the second phase of the experiment. In the second phase, three (3) higher doses $(1600$, 2900 and $5000 \mathrm{mg} / \mathrm{kg}$ ) of the extract were administered to a fresh batch of animals at one animal per dose. The animals were observed for clinical signs and symptoms of toxicity like behavioural changes and mortality within $24 \mathrm{~h}$. Lethal dose (LD $\left.\mathrm{L}_{50}\right)$ was then calculated as the geometric mean of the lowest lethal dose and highest non-lethal dose.

\section{Sub-chronic toxicity test}

Sub-chronic toxicity test was carried out as per internationally accepted protocol drawn under OECD 407 guidelines. Briefly, rats were randomly divided into four (4) groups of five animals each. The group 1 (control) received daily oral administration of the vehicle $(10 \mathrm{ml} / \mathrm{kg}$ of distilled water) whereas groups 2,3 , and 4 received 100,500 and $1000 \mathrm{mg} / \mathrm{kg}$ of NDE daily for $28 \mathrm{~d}$, respectively. All animals were observed twice daily for apparent signs of toxicity or behavioural alterations during the experimental period. At the end of the experiment (on the 29th day), blood samples were collected from overnight fasted rats and used for various biochemical estimations. The biochemical parameters: alanine aminotransferase (ALT, EC, and 2.6.1.2), aspartate aminotransferase (AST, EC, and 2.6.1.1), alkaline phosphatase (ALP, EC, 3.1.3.1) and serum total protein (TP) were estimated using standard procedures [11-13]. The hematological parameters: packed cell volume (PCV), hemoglobin concentration (HB) and total white blood cell (TWBC) count were estimated using standard methods $[14,15]$. Subsequently, the animals were sacrificed and essential organs (liver, heart, kidney and lungs) were removed and physically examined.

\section{Antidiabetic evaluation}

\section{Oral glucose tolerance test (OGTT)}

In this method, twenty-five (25) rats were divided into five (5) groups $(n=5)$ and treated as follows: group 1 (control group) received $10 \mathrm{ml} / \mathrm{kg}$ of distilled water; group 2 received a standard, $2.5 \mathrm{mg} / \mathrm{kg}$ glibenclamide (GLI) while groups 3,4 and 5 received 100 $\mathrm{mg} / \mathrm{kg}, 200 \mathrm{mg} / \mathrm{kg}$ and $400 \mathrm{mg} / \mathrm{kg}$ of NDE, respectively. The baseline blood glucose levels (BGL) were determined prior to oral administration of glucose $(2 \mathrm{~g} / \mathrm{kg})$ at 0 min and after 30,60 , and 120 min post treatment.

\section{Antidiabetic activity in alloxan-induced diabetic rats}

In this method, thirty (30) rats were divided into six groups $(\mathrm{n}=5)$. The dosage of extract/standard drug/animal groupings were as described above. The BGL were determined before the induction of diabetes. Diabetes was induced using alloxan monohydrate (SigmaAldrich Co., St. Louis, MO, USA). The rats were fasted for $12 \mathrm{~h}$ with free access to water prior to the administration of freshly prepared alloxan monohydrate $(100 \mathrm{mg} / \mathrm{kg}$; i. v.) dissolved in ice-cold normal saline. After $5 \mathrm{~d}$ of stabilization, the fasting BGL was determined by using a One Touch Ultra ${ }^{\circledR}$ glucometer (Lifescan; Johnson and Johnson, Milpitas, CA, USA). Animals having fasting BGL $\geq 200 \mathrm{mg} / \mathrm{dl}$ $(11.1 \mathrm{mmol} / \mathrm{l})$ were considered diabetic and used for the study. The BGL were monitored at 0 (pre-treatment) and at 1, 2, 3, 4 and $5 \mathrm{~h}$ post treatment. Treatment was continued daily for 7 consecutive days per oral. Fasting BGL were monitored on the 3rd and 7th $\mathrm{d}$. The percentage blood glucose reductions (PBGR) were calculated relative to pretreatment values.

\section{Statistical analysis}

Results are expressed as mean \pm SEM. One-way analysis of variance (ANOVA) followed by Dunnett's post hoc test was used to compare differences between groups using SPSS statistical software and $p<0.05$ was considered statistically significant.

\section{RESULTS}

\section{Acute toxicity study $\left(\mathbf{L D}_{50}\right)$}

The NDE gave an estimated $L_{50}>5000 \mathrm{mg} / \mathrm{kg}$. Also, no visible sign of toxicity or death was observed in the treated groups.

\section{Effect on biochemical parameters}

There were no significant $(p>0.05)$ differences in the values of serum biochemical parameters (ALT, AST, ALP and TP) assayed between the treated groups as compared with the control group (table 1).

Table 1: Effect of NDE on biochemical parameters

\begin{tabular}{llllll}
\hline Treatment & \multicolumn{7}{c}{ Dose $(\mathbf{m g} / \mathbf{k g})$ biochemical parameters } & ALP(U/I) & TP(mg/d) \\
\cline { 2 - 6 } & - & ALT(U/I) & AST(U/I) & $357.37 \pm 24.90$ & $6.88 \pm 0.18$ \\
NC & 100 & $20.59 \pm 1.30$ & $46.04 \pm 2.05$ & $409.53 \pm 33.02$ & $6.98 \pm 0.12$ \\
NDE & 500 & $22.53 \pm 2.17$ & $44.59 \pm 2.21$ & $316.33 \pm 28.39$ & $6.85 \pm 0.21$ \\
NDE & 1000 & $23.02 \pm 0.97$ & $50.45 \pm 1.99$ & $292.16 \pm 6.92$ & $7.05 \pm 0.16$ \\
NDE & & $49.61 \pm 0.97$ &
\end{tabular}

Each value represents the mean \pm SEM, $\mathrm{n}=5,{ }^{*} p<0.05$ compared with control (One-way ANOVA; Dunett's post hoc). NC-normal control, NDE- $N$. diderrichii extract.

\section{Effect on hematological parameters}

There were no significant $(p>0.05)$ differences in the values of the serum hematological parameters (PCV, HB, and TWBC) of the treated groups when compared with the control group. Although, the extract exhibited dose dependent increase in the HB values (table 2).

\section{Effect on organ weight}

The effect of the extract on organ weight is shown in table 3 . The organ weights of the treated groups were not significantly $(p>0.05)$ different from the control group.

\section{Effect in glucose loaded rats}

Expectedly, following oral administration of glucose meal, there was significant $(p<0.05)$ increase observed in the BGL of the control group at 30th min post glucose challenge. The oral administration of the extract $(100,200,400 \mathrm{mg} / \mathrm{kg})$ and GLI $(2.5 \mathrm{mg} / \mathrm{kg})$ suppressed the rise in BGL respectively at the 30 th min time compared with the control. The effect was sustained up to $120 \mathrm{~min}$. At this time, relative to the pretreatment values, no significant $(p>0.05)$ difference was observed in the BGL of NDE treated rats compared with pretreatment values (table 4).

\section{Effect in alloxan-induced diabetic rats}

The result showed that the extract considerably reduced the fasting BGL to varying degrees in diabetic rats. However, the PBGR was dose related as $400 \mathrm{mg} / \mathrm{kg}$ dose exhibited the highest PBGR of 21.46 and $25.80 \%$ at the 4 th and 5 th h respectively, while the $100 \mathrm{mg} / \mathrm{kg}$ was the least with 8.33 and $14.66 \%$ at the 4 th and 5 th $\mathrm{h}$ of monitoring respectively. The standard agent, GLI $(2.5 \mathrm{mg} / \mathrm{kg})$ exhibited the highest PBGR of $28.34 \%$ and $38.18 \%$ at the 4 th and 5th $\mathrm{h}$ respectively after administration (table 5 ). 
Table 2: Effect of NDE on hematological parameters

\begin{tabular}{|c|c|c|c|c|}
\hline \multirow[t]{2}{*}{ Treatment } & \multicolumn{4}{|c|}{ Dose (mg/kg) hematological parameters } \\
\hline & & PCV (\%) & HB (g/dl) & TWBC (x103/mm3) \\
\hline NC & - & $39.40 \pm 1.23$ & $14.40 \pm 0.45$ & $16.37 \pm 1.25$ \\
\hline NDE & 100 & $39.20 \pm 0.93$ & $14.53 \pm 0.46$ & $14.21 \pm 1.16$ \\
\hline NDE & 500 & $38.00 \pm 1.11$ & $14.56 \pm 0.28$ & $14.31 \pm 1.57$ \\
\hline NDE & 1000 & $39.40 \pm 0.29$ & $14.57 \pm 0.56$ & $14.73 \pm 1.44$ \\
\hline
\end{tabular}

Each value represents the mean \pm SEM, $\mathrm{n}=5,{ }^{*} p<0.05$ compared with control (One-way ANOVA; Dunett's post hoc). NC-normal control, NDE- $N$. diderrichii extract.

Table 3: Effect of NDE on organ weight

\begin{tabular}{|c|c|c|c|c|c|}
\hline \multirow[t]{2}{*}{ Treatment } & \multicolumn{5}{|c|}{ Dose (mg/kg) organ weight (g) } \\
\hline & & Liver & Heart & Kidney & Lungs \\
\hline NC & - & $3.76 \pm 0.29$ & $0.38 \pm 0.01$ & $0.39 \pm 0.02$ & $1.02 \pm 0.13$ \\
\hline NDE & 100 & $4.11 \pm 0.24$ & $0.42 \pm 0.03$ & $0.41 \pm 0.03$ & $1.02 \pm 0.07$ \\
\hline NDE & 500 & $3.52 \pm 3.52$ & $0.35 \pm 0.35$ & $0.37 \pm 0.34$ & $0.97 \pm 0.12$ \\
\hline NDE & 1000 & $3.99 \pm 0.15$ & $0.40 \pm 0.02$ & $0.35 \pm 0.14$ & $0.98 \pm 0.04$ \\
\hline
\end{tabular}

Each value represents the mean \pm SEM, $\mathrm{n}=5,{ }^{*} p<0.05$ compared with control (One-way ANOVA; Dunett's post hoc). NC-normal control, NDE- $N$. diderrichii extract.

Table 4: Effect of NDE in glucose loaded rats

\begin{tabular}{|c|c|c|c|c|c|}
\hline \multirow[t]{2}{*}{ Treatment } & \multicolumn{5}{|c|}{ Dose (mg/kg) blood glucose (mg/dl) } \\
\hline & & Pre-treatment & $30 \mathrm{~min}$ & $60 \mathrm{~min}$ & $120 \mathrm{~min}$ \\
\hline Control & - & $54.40 \pm 1.63$ & $161.60 \pm 13.80^{\#}$ & $148.20 \pm 5.59^{\#}$ & $128.2 \pm 6.09^{\#}$ \\
\hline GLI & 2.5 & $43.40 \pm 2.99$ & $96.60 \pm 7.81^{* \#}$ & $48.0 \pm 1.81^{*}$ & $47.0 \pm 2.21^{*}$ \\
\hline NDE & 100 & $55.0 \pm 5.54$ & $85.40 \pm 10.81^{* \#}$ & $65.60 \pm 5.08 *$ & $57.0 \pm 8.33^{*}$ \\
\hline NDE & 200 & $49.20 \pm 2.96$ & $60.40 \pm 6.55^{*}$ & $53.80 \pm 5.65^{*}$ & $49.2 \pm 3.17^{*}$ \\
\hline NDE & 400 & $52.30 \pm 3.91$ & $72.67 \pm 3.91^{*}$ & $53.0 \pm 3.19 *$ & $49.83 \pm 3.51^{*}$ \\
\hline
\end{tabular}

Each value represents the mean $\pm \mathrm{SEM}, \mathrm{n}=5,{ }^{*}, \# p<0.05$ compared with control and pretreatment values respectively (One-way ANOVA; Dunett's post hoc). GLI-glibenclamide, NDE- $N$. diderrichii extract.

Table 5: Effect of NDE in alloxan-induced diabetic rats

\begin{tabular}{|c|c|c|c|c|c|c|c|}
\hline \multirow{2}{*}{$\begin{array}{l}\text { Treat } \\
\text { ment }\end{array}$} & \multicolumn{7}{|c|}{ Dose (mg/kg) blood glucose (mg/dl) } \\
\hline & & Pre-treatment & $1 \mathrm{~h}$ & $2 \mathrm{~h}$ & $3 \mathrm{~h}$ & $4 \mathrm{~h}$ & $5 \mathrm{~h}$ \\
\hline DC & - & $482.4 \pm 72.07$ & $446.2 \pm 57.69$ & $440.6 \pm 52.42$ & $436.33 \pm 23.25$ & $425.48 \pm 10.32$ & $402.32 \pm 27.65$ \\
\hline GLI & 2.5 & $462.25 \pm 81.93$ & $\begin{array}{l}456.51 \pm 72.21 \\
(1.22)\end{array}$ & $\begin{array}{l}451.00 \pm 77.29 \\
(2.43)\end{array}$ & $\begin{array}{l}373.75 \pm 102.44^{* \#} \\
(19.16)\end{array}$ & $\begin{array}{l}331.25 \pm 104.58 * \\
\#(28.34)\end{array}$ & $\begin{array}{l}285.75 \pm 108.4^{*} \\
(38.18)\end{array}$ \\
\hline NDE & 100 & $386.5 \pm 58.97$ & $\begin{array}{l}420.50 \pm 62.10 \\
(-8.79)\end{array}$ & $\begin{array}{l}371.66 \pm 55.93^{*} \\
(3.84)\end{array}$ & $\begin{array}{l}367.67 \pm 62.17^{*} \\
(4.87)\end{array}$ & $\begin{array}{l}354.31 \pm 59.19^{*} \\
(8.33)\end{array}$ & $\begin{array}{l}329.83 \pm 71.52 \text { *\# } \\
(14.66)\end{array}$ \\
\hline NDEN & 200 & $370.5 \pm 70.68$ & $\begin{array}{l}349.25 \pm 82.1^{*} \\
(5.74)\end{array}$ & $\begin{array}{l}342.25 \pm 96.52^{*} \\
(7.63)\end{array}$ & $\begin{array}{l}309.74 \pm 53.76 \\
* \#(16.4)\end{array}$ & $\begin{array}{l}303.10 \pm 85.69^{* \#} \\
(18.2)\end{array}$ & $\begin{array}{l}300.46 \pm 89.77^{*} \\
(18.9)\end{array}$ \\
\hline $\mathrm{DE}$ & 400 & $415.75 \pm 106.42$ & $\begin{array}{l}409.25 \pm 111.8 \\
(1.56)\end{array}$ & $\begin{array}{l}369.75 \pm 128.9^{*} \\
(11.06)\end{array}$ & $\begin{array}{l}328.26 \pm 133.55^{* \#} \\
(21.04)\end{array}$ & $\begin{array}{l}326.5 \pm 136.92^{* \#} \\
(21.46)\end{array}$ & $\begin{array}{l}308.5 \pm 136.05^{\text {*\# }} \\
(25.80)\end{array}$ \\
\hline
\end{tabular}

Each value represents the mean $\pm \mathrm{SEM}, \mathrm{n}=5$, *\# $p<0.05$ compared with diabetic control and pretreatment values respectively. DC-diabetic control, GLI-glibenclamide, NDE- $N$. diderrichii extract. Values in parenthesis represent reduction (\%) in blood glucose level calculated relative to pretreatment values.

Effect of prolonged administration of NDE in alloxan-induced diabetic rats

Prolonged administration of different doses of the extract to diabetic rats for $7 \mathrm{~d}$ reduced the fasting BGL. The $200 \mathrm{mg} / \mathrm{kg}$ and $400 \mathrm{mg} / \mathrm{kg}$ exhibited the highest percentage blood glucose reduction of $70.94 \%$ and $83.74 \%$ at days 3 and 7 respectively compared to day 0 values and the diabetic control respectively. The reduction was slightly comparable to that of the reference drug GLI (53.98 and 92.86\%) (table 6).

Table 6: Effect of prolonged administration of NDE in alloxan-induced diabetic rats

\begin{tabular}{|c|c|c|c|c|}
\hline \multirow[t]{2}{*}{ Treatment } & \multicolumn{4}{|c|}{ Dose (mg/dl) blood glucose (mg/dl) } \\
\hline & & Day 0 & Day 3 & Day 7 \\
\hline $\mathrm{DC}$ & - & $482.4 \pm 72.07$ & $254.75 \pm 28.11$ & $261.02 \pm 22.27$ \\
\hline GLI & 2.5 & $462.25 \pm 81.93$ & $212.75 \pm 93.12^{\#([53] \cdot[98])}$ & $33.00 \pm 18.00^{* \#([92] \cdot[86])}$ \\
\hline NDE & 100 & $386.5 \pm 58.97$ & $191.3 \pm 13.57^{* \#([46] \cdot[53])}$ & $88.75 \pm 19.12^{* \#([75] \cdot[11])}$ \\
\hline NDE & 200 & $370.5 \pm 70.68415 .8 \pm 106.42$ & $107.67 \pm 8.57^{* \#([70] \cdot[94])}$ & $73.33 \pm 11.7^{* \#([80] \cdot[21])}$ \\
\hline NDE & 400 & & $133.75 \pm 47.2^{* \#([67] \cdot[83])}$ & $67.00 \pm 22.8^{* \#([83] \cdot[74])}$ \\
\hline
\end{tabular}

Each value represents the mean $\pm \mathrm{SEM}, \mathrm{n}=5$, *, $p<0.05$ compared with diabetic control and day 0 values respectively (One-way ANOVA; Dunett's post hoc). DC-diabetic control, GLI-glibenclamide, NDE-N. diderrichii extract. Values in parenthesis represent reduction (\%) in blood glucose level calculated relative to day 0 values. 


\section{DISCUSSION}

The role of plant extracts in diabetes management has been tried by many researchers. Diabetes mellitus (DM) was induced using intravenous alloxan, a known diabetogen. Alloxan causes an increase in blood glucose levels or hyperglycemia and glucose intolerance or syndromes similar to either type 1 or types 2 DM [16]. Hyperglycemia is associated with the generation of reactive oxygen species (ROS) causing oxidative damage particularly to the heart, kidney, eyes, nerves, liver, small and large vessels and gastro intestinal system [17]. Thus, the increased blood glucose concentration is as a result of intrinsic oxidative stress in diabetic condition, a result that is consistent with several studies in rats $[18,19]$.

In the present study, oral administration of NDE exhibited significant hypoglycemic activity in normoglycemic and alloxaninduced diabetic rats. The reduction in blood glucose levels is indicative that the extract has possible hypoglycemic activity. Thus, it is suggestive of the confirmation of its glucose lowering effect. This effect was comparable to that of glibenclamide, the standard drug used in the study. Glibenclamide belongs to the sulfonylurea class of oral drugs that reduce blood glucose levels by stimulating insulin secretion. In the presence of viable pancreatic $\beta$ cells, sulfonylureas stimulate the release of endogenous insulin from the pancreatic $\beta$ cells, thereby reducing blood glucose levels [20]. Plant extracts are well known to favour regeneration of islet beta cells as their primary mechanism of action $[21,22]$. Hence, the mechanism through which NDE mediates this hypoglycemic effect could be by stimulating insulin secretion probably, through enhancing the sensitivity of beta cells to glucose, resulting in increased insulin release. Furthermore, bioactive compounds in medicinal plants play an important role in diabetes management [23]. The previous study has shown the presence of alkaloid, flavonoids, saponins and other chemical compounds in the plant extract [24]. Several of these constituents are well known for their antidiabetic activity $[25,26]$. This suggests that the antidiabetic activity of the extract may be partly due to the action of these phytoconstituents which could act synergistically or independently in reducing the blood glucose level.

In the normoglycemic rats, the lack of significant alterations observed in the levels of aspartate transaminase (AST), alanine transaminase (ALT) and alkaline phosphatase (ALP), which are good indicators of liver function, suggests that the extract has no harmful effect on the liver. The liver plays an essential role in various metabolic processes and is, therefore, severely affected during exposure to the toxic effects of exogenous compounds [27]. AST, ALT and ALP are important serum biomarker enzymes usually measured to evaluate liver damage or the toxic effect of drugs on liver [28]. Higher values of serum ALT and AST have been implicated in liver necrosis, hepatitis, toxic liver disease and acute myocardial infarction [29]. Similarly, no significant differences were observed in the hematological parameters (PCV, HB, and TWBC) between the treated groups and the control. Analysis of hematological parameters in animal studies is relevant to evaluate the risk of alterations of the hematopoietic system in toxicity studies, for necessary application to humans [30]. The lack of significant changes observed could be attributed to the extract not being toxic to circulating red cells, nor interfered with their production and that of platelets [31].

The relative weight of the organs (heart, lungs, kidney and liver) in the treated groups showed no significant $(p<0.05)$ difference as compared with the control (table 4). These organs are considered highly useful in toxicity studies because of their sensitivity to harmful compounds and their potential to predict toxicity [32]. Hence, the non-significant differences observed indicate that, at the oral dose administered, NDE can be considered as non-toxic.

\section{CONCLUSION}

In conclusion, the result of the present study has shown that the root bark extract of $N$. diderrichii possesses potent antidiabetic activity with relatively no or minimal toxicity. Further research on the isolation and characterization of the active phytoconstituents is ongoing.

\section{ACKNOWLEDGEMENT}

The authors acknowledge the technical assistance of Mr. Chimezue Osigwe and Mr. Ifeanyi Ijeh of the Department of Pharmacology and Toxicology, University of Nigeria.

\section{AUTHORS CONTRIBUTION}

All authors contributed equally in designing, performing the experiment and writing up of the research work.

\section{CONFLICT OF INTERESTS}

The authors declare no conflict of interest regarding the manuscript

\section{REFERENCES}

1. Komalavalli T, Packia LM, Muthukumarasamy S, Mohan VR. Antidiabetic and antihyperlipidemic activity of Sonerila tinnevelliensis fischer whole plant in alloxan induced diabetic rats. Int J Curr Pharm Res 2015;7:53-7.

2. Malini P, Kanchana G, Rajadurai M. Antidiabetic efficacy of ellagic acid in streptozotocin-induced diabetes mellitus in albino Wistar rats. Asian J Pharm Clin Res 2011;4:124-8.

3. Osigwe CC, Akah PA, Nworu CS, Okoye TC, Tchimene MK. Antihyperglycemic studies on the leaf extract and active fractions of Newbouldia laevis (Bignoniaceae). Pharmacol Pharm 2015;6:518-32.

4. Ezuruike UF, Prieto JM. The use of plants in the traditional management of diabetes in Nigeria: pharmacological and toxicological considerations. J Ethnopharmacol 2014;155:857-924.

5. Lamidi M, Ollivier E, Gasquet M, Faure R, Nze-Ekekang L, Balansard G. Structural and antimalarial studies of saponins from Nauclea diderrichii bark. Adv Exp Med Biol 1996;404:383-99.

6. Mustofa VA, Benoit-Vical F, Pelissier Y, Kone-Bamba D, Mallie M. Antiplasmodial activity of plant extracts used in West African traditional medicine. J Ethnopharmacol 2000;73:145-51.

7. Di Giorgio C, Lamidi M, Delmas F, Balansard G, Ollivier E. Antileishmanial activity of quinovic acid glycosides and cadambine acid isolated from Nauclea diderrichii. Planta Med 2006; 72:1396-402.

8. Nwodo NJ, Agbo MO. Antitrypanosomal effects of methanolic extracts of Nauclea diderrichii (Merr) and Spathodea campanulata stem bark. J Pharm Allied Sci 2010;7:1219-27.

9. Orwac C, Mutua A, Kindt R, Jamnadass R, Simons A. Agroforestree database: a tree reference and selection guild version 4.0; 2009. Available from: http:// www. worldagroforestry.org/af/treedbl. [Last accessed on $06 \mathrm{Apr}$ 2017]

10. Lorke D. A new approach to practical acute toxicity testing. Arch Toxicol 1983;54:272-89.

11. Reitman S, Frankel SA. Colourimetric method of determination of serum glutamicoxaloacetic and glutamic pyruvic transaminase. Am J Clin Pathol 1957;28:56-63.

12. Rec GSCC. Determination of alkaline phosphatase. J Clin Chem Clin Biochem 1972;10:281-91.

13. Cheesbrough M. Medical laboratory manual for tropical countries. 2nd ed. ELSB: Cambridge; 1991. p. 508-11.

14. Ramnik S. Methods and interpretations in medical laboratory technology. 4th ed. India: Medical Publishers Ltd; 1994. p. 184-99.

15. Schalm OW, Jain NC, Carol EJ. Textbook of veterinary hematology. 2nd ed. Philadephia: Lea and Febiger; 1975. p. 192-250.

16. Fröde TS, Medeiros YS. Animal models to test drugs with potential antidiabetic activity. J Ethnopharmacol 2008;115:173-83.

17. Tunali S, Yanardag R. Effect of vanadyl sulfate on the status of lipid parameters and on stomach and spleen tissues of streptozotocin-induced diabetic rats. Pharmacol Res 2006;53:271-7.

18. Niranjan PS, Singh D, Prajapati K, Jain SK. Antidiabetic activity of ethanolic extract of Dalbergia sissoo L. leaves in alloxan-induced diabetic rats. Int J Curr Pharm Res 2010; 2:24-7. 
19. Sujith K, Darwin RC, Roosewelt C. Antidiabetic activity of methanolic extract of Butea frondosa leaves with its mechanism of action. Asian J Pharm Res 2011;4:93-8.

20. Obi BC, Okoye TC, Joshua PE, Onyeto CA, Alumanah EO. Comparative study of the antidiabetic and biochemical effects of metformin, glibenclamide and repaglinide in alloxan-induced diabetic rats. Afr J Pharm Pharmacol 2015;9:1026-36.

21. Spasov AA, Maxeiner MP, Bulanov AF. Antidiabetic properties of Gymnema sylvestre. Pharm Chem J 2008;42:626-9.

22. Akah PA, Uzodinma SU, Okolo CE. Antidiabetic activity of aqueous and methanol extract and fractions of Gongronema latifolium (Aselepidaceae) leaves in alloxan-induced diabetic rats. J Appl Pharm Sci 2011;1:99-102.

23. Omoniwa BP, Luka CD. Antidiabetic and toxicity evaluation of aqueous stem extract of Ficus asperifolia in normal and alloxaninduced diabetic albino rats. Asian J Exp Biol Sci 2012;3:726-32.

24. Agnaniet H, Mbot EJ, Keita O, Fehrentz JA, Ankli A, Gallud A, et al. Antidiabetic potential of two medicinal plants used in Gabonese folk medicine. BMC Complementary Altern Med 2016;16:1-8.

25. Cazarolli LH, Zanatta L, Alberton EH, Figueiredo MS, Folador P, Damazio RG, et al. Flavonoids: cellular and molecular mechanism of action in glucose homeostasis. Mini Rev Med Chem 2008;8:1032-8.

26. Osadebe PO, Uzor PF, Omeje EO, Agbo MO, Obonga WO. Hypoglycemic activity of the extract and fractions of Anthocleista vogelii (Planch) stem bark. Trop J Pharm Res 2014;13:1437-43.
27. Ogbonnia SO, Mbaka GO, Nkemehule FE, Emordi JE, Okpagu NC, Ota DA. Acute and subchronic evaluation of aqueous extracts of Newbouldia laevis (Bignoniaceae) and Nauclea latifolia (Rubiaceae) roots used singly or in combination in Nigerian traditional medicines. Br J Pharmacol 2014;5:55-62.

28. Ramaiah SK. Preclinical safety assessment: current gaps, challenges and approaches in identifying translatable biomarkers of the drug induced liver. Clin Lab Med 2011;31:161-72.

29. Aguwa CN, Aguiyi JC. Liver disease. In: Aguwa CN. editor. Therapeutic basis of clinical pharmacyin the tropics. Enugu, Nigeria: SNAAP Press Ltd; 2004. p. 528-40.

30. Olson H, Betton G, Robinson D, Karluss T, Monro A, Kolaja G, et al. Concordance of the toxicity of pharmaceuticals in humans and in animals. Regul Toxicol Pharmacol 2000;32:56-67.

31. Mukinda JT, Syce JA. Acute and chronic toxicity of the aqueous extract of Artemisia afra in rodents. J Ethnopharmacol 2007;112:138-44.

32. Bello I, Bakkouri AS, Tabana YM, Al-Hindi B, Al-Mansoub MA, Mahmud R, et al. Acute and sub-acute toxicity evaluations of the methanolic extract of Alstonia scholaris stem bark. Med Sci 2016;4:1-14.

\section{How to cite this article}

- $\quad$ Theophine C Akunne, Bonaventure C Obi, Martha N Ofokansi, Patience C Nwonu, Charles 0 Okoli. Antidiabetic activity and toxicological evaluation of the methanol-dichloromethane root bark extract of Nauclea diderrichii (de wild) merr. Int J Pharm Pharm Sci 2017;9(9):279-283. 